\title{
Greener Approaches in the Textile Industry
}

\author{
Asim Kumar Roy Choudhury* \\ Department of Textile Technology, KPS Institute of Polytechnic, India
}

Submission: January 10, 2020; Published: February 11, 2020

*Corresponding author: Asim Kumar Roy Choudhury, Department of Textile Technology, Principal, KPS Institute of Polytechnic, Ex-professor, The Government College of Engineering and Textile Technology, Serampore, West Bengal, India

Keywords: Textile industries; Human civilisation; Textile wastewater; Industrial sectors; Toxic chemicals; Solid waste accumulation; Pollution; Environmental impact

\section{Mini Review}

Textile industries are backbone of human civilisation. Conventional textile industry is one of the most polluting industries on the planet being responsible for as much as $20 \%$ of pollution of our rivers and lands. When considering both the volume generated and the composition of effluent, textile wastewater is considered to be the most polluted of all industrial sectors. It is very difficult to control the robust and very complex global textile supply chain involving many branches of production, many countries engaged in textile production and innumerable companies and personnel working in these fields. The life cycles of textiles and clothing are unsustainable because of very high consumption of water, energy and toxic chemicals (which may even carried forward by the final product), generation of huge waste which accumulates in river, ponds and agricultural lands. The heavy transportation consumes huge quantity of fossil fuels. The use of excessive packing materials for marketing causes solid waste accumulation. Green chemistry is based on 12 principles and aims to reduce the adverse environmental impact of chemical processes and products through Life Cycle Analysis (LCA). The adverse environmental impact of chemical processes and products is assessed by Life Cycle Analysis (LCA) and appropriate actions are taken to reduce harmful effects at every stage of product life. Green chemistry targets for zero waste. The E factor, i.e. the ratio of the mass of waste to that of the product is calculated. For greener processes E-factor should be low while for the complete green process, E-factor must be zero. The terms environmentally friendly, eco-friendly, nature friendly, and green are used to refer to goods and services, laws, guidelines and policies claimed to inflict minimal or no harm on the environment. The companies sometimes use eco-labels to promote marketing of environmental friendly goods and services.
The following categories of substances are considered as noneco-friendly:

a. Non-biodegradable organic materials,

b. Hazardous substances,

c. Accident prone substances.

\section{Hazardous Chemicals}

According to American Occupational Safety and Health Administration, a highly hazardous chemical is a substance that is both toxic and reactive and whose potential for human injury is high if released. Highly hazardous chemicals may cause cancer, birth defects, genetic damage, miscarriage, injury and death from relatively small exposures. Hazardous substances may be classified into two groups on the basis of toxicity namely:

i. Toxic heavy metals

ii. Volatile organic solvents

Sustainability of textile processing can be improved by several ways, such as:

a) Substituting unsustainable textile materials and chemicals by greener organic and biodegradable materials

b) Eliminating or minimising the use of toxic chemicals in production and packing

c) Minimising the use of water and chemicals and recycling, wherever possible

d) Minimising the consumption of energy and fuel in production and transport 
e) Minimising generation of waste and safer disposal of waste

f) Strict management of environmental issues

Sustainable production and consumption can be achieved only if industrialists, retailers and consumers take ecological factors into account in every decision-making process. There has been an increasing awareness that many products could be produced under better conditions with greater respect for the environment.
CC (i) This work is licensed under Creative

(1) Commons Attribution 4.0 Licens

DOI: 10.19080/CTFTTE.2020.05.555679

\section{Your next submission with Juniper Publishers will reach you the below assets}

- Quality Editorial service

- Swift Peer Review

- Reprints availability

- E-prints Service

- Manuscript Podcast for convenient understanding

- Global attainment for your research

- Manuscript accessibility in different formats ( Pdf, E-pub, Full Text, Audio)

- Unceasing customer service

Track the below URL for one-step submission https://juniperpublishers.com/online-submission.php 